\title{
Pola Penggunaan Media Sosial Whatsapp Dalam Pemenuhan Informasi Mahasiswa Universitas Terbuka Mataram
}

\author{
Windi Baskoro Prihandoyo ${ }^{1}$, R Sudarwo ${ }^{2}$, Nining Suryani ${ }^{3}$ \\ 1Department of Communication and Information Science, Faculty of Social and Political Science, Universitas Terbuka, \\ windi@ecampus.ut.ac.id \\ 2Department of Basic Education Elementary School Teacher Education Study Program (PGSD),Universitas Terbuka, \\ sudarwo@ecampus.ut.ac.id \\ 32Departemen of Economi, Universitas Terbuka, niningsuryani@ecampus.ut.ac.id
}

\section{INFO ARTIKEL}

Riwayat Artikel:

Diterima: 08 September 2020

Disetujui: 30 September 2020

\section{Kata Kunci:}

Pola penggunaan

Informasi

Komunikasi

Media sosial

WhatsApp

ABSTRAK

Abstrak: Penelitian ini bertujuan untuk mengidentifikasi dan menganalisis pola penggunaan media sosial WhatsApp dalam pemenuhan informasi mahasiswa Universitas Terbuka Mataram. Metode yang digunakan dalam penelitian ini adalah survei korelasional deskriptif. Hasil penelitian ini adalah: 1. Frekuensi dan waktu yang digunakan oleh responden dalam mencari informasi di komunitas WhatsApp tergolong tinggi. Jenis informasi yang paling banyak dicari oleh responden adalah tutorial dan nilai. Faktor kepemilikan TIK dan motif mencari informasi memiliki hubungan yang sangat nyata dengan pola penggunaan komunitas WhatsApp, sedangkan faktor jenis kelamin, umur, pekerjaan dan informasi yang paling banyak dicari tidak memiliki hubungan yang nyata. 2. Tingkat pemenuhan kebutuhan informasi mahasiswa melalui komunitas WhatsApp tergolong tinggi. Faktor pola penggunaan komunitas WhatsApp seperti jumlah hari kunjungan, jumlah kunjungan, dan jumlah waktu kuncungan memiliki hubungan yang sangat nyata dengan tingkat pemenuhan informasi mahasiswa.
\end{abstract}

\begin{abstract}
This study aims to identify and analyze pattern of the use of WhatsApp social media in fulfilling information of students of Mataram Open University. The method used in this research is a descriptive correlational survey. The results in this study: 1 . The frequency and time spent by respondents in finding information in the WhatsApp community is high. The types of information most sought by respondents were tutorials and grades. ICT ownership factors and information seeking motives have a very real relationship with WhatsApp community usage patterns, while the sexes, age, occupations and information that are most sought after do not have a real relationship. 2. The level of fulfillment of student information needs through the WhatsApp community is high. Factor patterns of use of the WhatsApp community such as the number of visit days, the number of visits, and the amount of time the kuncungan has a very real relationship with the level of student information fulfillment.
\end{abstract}

\section{A. LATAR BELAKANG}

Perkembangan ilmu pengetahuan dan teknologi (TIK) yang pesat ditandai dengan adanya penemuan dan pengembangan media TIK dan aplikasi yang ramah dalam penggunaan. Perkembangan ini ditunjang dengan semakin luasnya jaringan internet hingga menjangkau daerah-daerah pelosok memiliki pengaruh pada tingkat penggunaan oleh masyarakat. Tingginya tingkat penggunaan TIK dan jaringan internet oleh masyarakat dapat menghilangkan batas ruang dan waktu. Batas ruang geografis yang sebelumnya menjadi persoalan menjadi hilang dengan hadir new media, batas ruang dan waktu menjadi nol, karena keberadaan teknologi yang bisa memangkas batas ruang dan waktu. (1)
Universitas Terbuka (UT) merupakan pelopor penyelenggara pendidikan tinggi yang menerapkan sistem pendidikan tinggi jarak jauh (PTJJ) di Indonesia. Jarak jauh disini berarti pembelajaran yang dilakukan di UT tidak harus dilakukan secara tatap muka, tapi memanfaatkan beberapa media dalam proses pembelajarannya. Media pembelajaran yang digunakan oleh UT antara lain, yaitu media cetak (buku materi pokok) maupun media noncetak (audio/video), komputer/internet, siaran radio,dan televisi.

Perkembangan ilmu pengetahuan yang sangat pesat ini mengharuskan UT sebagai penyelenggara PTJJ untuk mampu beradaptasi dengan mengembangkan berbagai media pembelajaran yang ada. Universitas Terbuka harus mampu melakukan berbagai inovasi media pembelajaran sesuai dengan perkembangan teknologi. 
Berbagai peralatan atau media TIK berhasil diciptakan dan dikembangkan dengan memanfaatkan perkembangan ilmu pengetahuan. Tujuan utama diciptakan dan pengembangan ini adalah untuk mempermudah hidup manusia. Salah satu media yang banyak digunakan atau dimanfaatkan oleh masyarakat adalah handphone (HP).

Pesatnya perkembangan ilmu pengetahuan memiliki dampak yang sangat signifikan terhadap peningkatan kemampuan dari HP. Sebelumnya pemanfaatan HP hanya sebatas telepon dan sms. Penambahan teknologi yang canggih dalam HP serta ditunjang dengan pengembangan aplikasi yang semakin beragam dan mudah dalam penggunaannya memiliki dampak pada perubahan komunikasi, diseminasi dan akses informasi menjadi tanpa batas.

Berbagai aplikasi diciptakan sesuai dengan kebutuhan manusia. Salah satu aplikasi yang banyak digunakan untuk berkomunikasi dan mencari informasi adalah media sosial (facebook, line, dan WhatsApp). Media sosial merupakan sebuah media dalam jaringan (daring) dimana para penggunanya dapat berpartisipasi, berbagi, dan menciptakan isi meliputi blog, wiki, forum dan dunia virtual. Media sosial hingga kini menjadi salah satu media komunikasi yang paling banyak digunakan oleh manusia untuk bersosialisasi dengan manusia lainnya di dunia maya. (2) Linch mengungkapkan informasi baru tentang penggunaan media sosial, promosi koleksi digital, dan / atau penjangkauan oleh organisasi yang terlibat dalam perpustakaan digital terdistribusi nasional. Twitter adalah pilihan paling populer di antara platform media sosial dengan 19 dari 27 hub yang disurvei secara aktif atau sebelumnya menge-tweet. Facebook berada di urutan kedua dengan 15 akun aktif. Platform lain yang digunakan oleh hub termasuk Tumblr, Instagram, Pinterest, dan Flickr, meskipun hanya sedikit atau hub yang mengandalkan platform ini. Konten biasanya tidak berbeda secara signifikan di beberapa akun media sosial; sebagian besar hub dengan beberapa akun media sosial berbagi konten umum yang sama di setiap platform pada atau sekitar tanggal dan waktu yang sama dengan perubahan kecil yang sesuai dengan platform tertentu (seperti versi teks yang dipersingkat dalam kiriman Facebook untuk Tweet untuk mematuhi peraturan Twitter batas karakter). Sebagian besar umpan media sosial menerima banyak interaksi dari pengguna, dalam bentuk suka, retweet, bagikan, pin ulang, reblog, dll. Tetapi sangat sedikit yang secara konsisten memicu komentar oleh pengguna dan bahkan lebih sedikit lagi melihat interaksi antara pengguna atau pengguna dan staf. Sementara hub layanan terutama berkaitan dengan agregasi metadata objek digital, sebagian besar akun media sosial mereka menunjukkan bahwa berbagi objek digital hanyalah sebagian dari konten dan prioritas mereka. Hanya akun Tumblr, Pinterest, dan Flickr yang secara konsisten dikhususkan untuk hampir seluruhnya objek digital atau berbagi koleksi. Akun media sosial lainnya didedikasikan untuk ini dan konten lainnya, seperti berbagi informasi yang berguna bagi penyedia atau pengguna hub, promosi acara, proyek, atau produk, posting berdasarkan peristiwa mendesak seperti liburan atau momen penting dalam sejarah, atau posting murni untuk hiburan (1).

Media sosial saat ini juga dimanfaatkan oleh masyarakat untuk membentuk komunitas-komunitas tertentu sesuai dengan kebutuhan mereka. Berkaitan dengan pembentukan komunitas ini Haryanto (2016) dalam hasil penelitiannya menyatakan bahwa permasalahan yang dihadapi oleh hampir semua perpustakaan adalah keterbatasan koleksi, sehingga diperlukan usaha seperti sharing koleksi (resources sharing). Media sosial dalam penggunaannya dapat dimanfaatkan untuk membentuk komunitas-komunitas sejenis atau homogeny sehingga dapat berkomunikasi secara cepat untuk sharing koleksi. Efektivitas resources sharing perpustakaan perguruan tinggi melalui media sosial memerlukan beberapa hal antara lain kesamaan komunitas jurusan/homogeny, admin utama pengendali, kesepakatan resources sharing, kesepakatan resources sharing, no rekening Bank, jasa ekspedisi serta MoU (2). Penggunaan Media Sosial Sebagai Sarana Komunikasi Bagi Komunitas menunjukkan bahwa Akademi Berbagi Surakarta menggunakan media sosial seperti twitter, facebook, dan blog sebagai sarana komunikasi untuk memberikan informasi kelas, pendaftaran kelas, pencarian guru, tempat dan volunteer, koordinasi, sapaan, live tweet, menjalin kerjasama, berbagi foto, komunikasi dengan Akber kota lain, dan komunikasi dengan akun lainnya. Penggunaan media sosial sebagai sarana komunikasi bagi Akademi Berbagi Surakarta dinilai efektif karena dapat mudah dan cepat dalam menyebarluaskan informasi kepada khalayak tanpa memikirkan jarak, ruang, dan waktu (3).

Komunitas Historia Indonesia (KHI) dalam melaksanakan kegiatannya memanfaatkan media social sebagai sarana informasi, rekrutmen, edukasi, interaksi dan komunikasi, dan menciptakan sebagai strategi yang dilakukan KHI untuk menjadi pengajar sejarah dan budaya dan menjangkau publik yang memiliki minat dan misi yang sama untuk melestarikan sejarah. Teknik social media marketing diterapkan oleh KHI untuk menciptakan ruang bagi publik dalam mengolah minat dan membentuk gaya hidup yang cinta sejarah, sehingga diharapkan KHI semakin memperkuat identitasnya sebagai komunitas sejarah terbesar di Indonesia (4). Mahasiswa UT sebagai dalam menempuh studi pendidikan tinggi memanfaatkan media sosial WhatsApp untuk membentuk komunitas-komunitas mahasiswa sebagai upaya mempermudah dalam penyebaran dan pencarian informasi administrasi dan akademik.

Perkembangan TIK yang pesat dan banyak ditemukan dan diciptakannya media serta aplikasi yang 
memudahkan kehidupan manusia memiliki yang signifikan terhadap pemenuhan kebutuhan informasi. Hal ini sesuai dengan hasil penelitian Lusiana tentang Pengaruh Penggunaan Media Sosial Instagram Terhadap Pemenuhan Kebutuhan Informasi Kuliner Para Followers Akun@ Jktfoodbang yang menyatakan bahwa terdapat pengaruh yang signifikan antara penggunaan media sosial Instagram terhadap pemenuhan kebutuhan informasi kuliner para followers akun @jktfoodbang (5). Hal ini serupa dengan hasil penelitian yang menyatakan bahwa adanya pengaruh media instagram terhadap pemenuhan informasi followernya.(6);(7)

Tingkat pemenuhan kebutuhan informasi petani melalui radio komunitas tergolong tinggi namun berbeda hasilnya pada masing-masing pendengar radio. Faktor yang berhubungan nyata dengan tingkat pemenuhan kebutuhan informasi melalui radio komunitas adalah frekuensi mendengarkan radio, sedangkan faktor yang berhubungan sangat nyata dengan tingkat pemenuhan kebutuhan informasi adalah durasi mendengarkan radio komunitas. Selanjutnya Atikah dkk menyatakan bahwa implikasi penelitian ini mendukung Teori Uses and Gratification memiliki kaitan dengan latar belakang sosial dan psikologis, kebutuhan, harapan, media massa atau sumber-sumber lain yang menyebabkan terbentuknya pola terpaan media, sehingga perlu adanya gratifikasi dan konsekuensi lainnya, yang mungkin sebagian besar tidak diinginkan. Alasan orang menggunakan dan menerapkan model Uses and Gratification relevan terhadap media karena anggota khalayak dianggap secara aktif menggunakan media untuk memenuhi kebutuhannya (8). Terdapat tiga pola komunikasi dalam memelihara solidaritas jamaah, yaitu pola komunikasi aksi, pola komunikasi solidaritas, dan pola transaksi. Selanjutnya Nurjaman menyatakan bahwa identitas komunikasi kyai dipengaruhi melalui personal layer, enactment layer, relational dan communal yang kesemuanya membentuk sebuah identitas komunikasi (9).

Berkaitan dengan pola komunikasi menggunakan media sosial WhatsApp, Joko mengungkapkan bahwa pola komunikasi anak dengan orang tua di perantauan menggunakan media sosial WhatsApp sebagai alat komunikasi menggunakan pola komunikasi satu arah dan dua arah. Pola ini memungkinkan sebagai penunjang dan sebagai cara untuk melakukan hubungan komunikasi jarak jauh (10). Penelitian sejenis yang dilakukan oleh Permata menunjukkan bahwa pola komunikasi yang digunakan adalah pola konsensual dengan intensitas percakapan hampir terjalin setiap hari. Hambatan yang terjadi dalam komunikasi jarak jauh ini adalah hambatan teknis, hambatan semantik, dan hambatan manusiawi (11).

Pemanfaatan media sosial WhatsApp Group di Fakultas Ekonomi Islam sebagai media penyebaran informasi, media diskusi dan mendidik, media hiburan, serta sebagai media untuk memberikan pengaruh dan pembuatan kebijakan di lingkungan Fakultas Ekonomi Islam Universitas Djuanda Bogor sangat besar (12). Pustakawan dalam keseharian di perpustakaan UIN Sunan Kalijaga cenderung menggunakan media sosial daripada melakukan komunikasi interpersonal secara langsung. Dampak kehadiran media sosial adalah mengubah sikap dan gaya hidup pustakawan dari pustakawan yang ramah menjadi cuek dengan keadaan disekitarnya (13). Berdasarkan uraian di atas, maka perlu dikaji lebih lanjut tentang Pola Penggunaan Media Sosial WhatsApp dalam Pemenuhan Informasi Mahasiswa Universitas Terbuka Mataram.

\section{B. METODE PENELITIAN}

Penelitian ini menggunakan metode survey deskriptif korelasional. Metode survey deskriptif korelasional digunakan untuk mengetahui mengapa suatu kondisi mempengaruhi terjadinya sesuatu dan menjelaskan mengapa fenomena ini terjadi dan apa pengaruhnya. Jenis penelitian ingin menjelas hubungan dua variabel atau lebih (3). Penelitian ini berupaya menggambarkan tindakan mahasiswa dalam menggunakan komunitas media sosial WhatsApp, menganalisis dan menjelaskan faktor-faktor yang berhubungan dengan pola penggunaan tersebut. Penelitian ini berupaya untuk menggali informasi dari mahasiswa tentang motif informasi dalam menggunakan komunitas media sosial WhatsApp, dilanjutkan dengan menganalisis aspek penggunaannya, seperti frekuensi, durasi, pilihan jenis informasi, dan partisipasi mahasiswa dalam kegiatan kemahasiswaan. Langkah selanjutnya adalah menganalisis tingkat pemenuhan kebutuhan informasi mahasiswa melalui komunitas media sosial WhatsApp.

Populasi dalam penelitian ini adalah mahasiswa Universitas Terbuka Mataram yang tergabung dalam komunitas mediao sosial WhatsApp dan berstatus aktif serta telah melakukan registrasi mata kuliah periode 2019.1. Survey awal dalam pendataan komunitas media sosial WhatsApp mahasiswa diperoleh data sebanyak 30 komunitas media sosial WhatsApp dengan jumlah anggota sebanyak 1.178 orang. Teknik pengambilan sampeldalampenelitianini menggunakan metode acak sederhana dengan teknik pengambilan sampel menggunakan quota sampling sebanyak 25\% dari keseluruhan populasi, yaitu 295 orang.

Penelitian ini menggunakan instrumen dalam bentuk kuesioner. Sofwater yang digunakan untuk olah data adalah Statistica Package for Social Sciense (SPSS) versi 20.0. Selanjutnya data dianalisis secara deskriptif berupa distribusi frekuensi dan analisis inferensial. Untuk menentukan hubungan antara peubahn digunakan uji korelasi Rank Spearman. 
sebanyak 197 orang $(66,8 \%)$ dan tua sebanyak 87 orang (29,5\%).

\section{HASIL DAN PEMBAHASAN}

Penelitian ini dilaksanakan di UT Mataram dengan wilayah kerja meliputi seluruh kabupaten kota yang ada di Provinsi Nusa Tenggara Barat, antara lain: Kota Mataram, Kabupaten Lombok Barat, Kabupaten Lombok Tengah, Kabupaten Lombok Utara, Kabupaten Lombok Timur, Kabupaten Sumbawa Barat, Kabupaten Sumbawa, Kabupaten Dompu, Kabupaten Bima, dan Kota Bima.

\section{Karakteristik Mahasiswa UT Mataram (X1)}

Pemanfaatan media TIK dalam proses pembelajaran sudah dilakukan oleh mahasiswa UT Mataram, khususnya untuk mencari dan berbagi informasi dengan sesama mahasiswa. Salah satu media TIK yang digunakan adalah smartphone yang saat ini dengan berbagai kelebihannya mampu memfasilitasi penggunanya untuk mengakses dan mendiseminasikan informasi. hal ini ditunjang dengan semakin banyak aplikasi yang dikembangan untuk mempermudah pengguna smartphone. Salah satu aplikasi yang dikembangkan dan banyak digunakan oleh mahasiswa UT Mataram adalah WhatsApp.

Mahasiswa memanfaatkan aplikasi ini untuk membentuk komunitas-komunitas belajar dan berbagi informasi antar sesama anggota. Hingga saat pelaksanaan penelitian ini dilaksanakan terdapat 30 grup komunitas mahasiswa dengan jumlah anggota sebanyak 1.178 orang $(52,83 \%)$.

Berdasarkan hasil penelitian tentang karakteristik mahasiswa UT Mataram diketahui bahwa bahwa mahasiswa UT Mataram sebagian besar perempuan yaitu sebanyak 195 orang $(66,1 \%)$. Hal ini menunjukkan bahwa tingkat kesadaran perempuan akan pentingnya pendidikan sudah tinggi. Pemahaman dan pemikiran tentang posisi dan peran sudah mulai berubah. Orang tidak lagi berpikiran anak-anak perempuan tidak memerlukan sekolah hingga ke jenjang yang lebih tinggi karena akhirnya hanya akan mengurus rumah tangga dan yang bekerja adalah suaminya. Hal ini juga menunjukkan bahwa sudah munculnya kesadaran orang tua tentang kesamaan hak dan kewajiban dalam mendidik anak-anaknya. Orang tua sudah tidak lagi membedakan hak pendidikan anak-anaknya. Ini ditunjukkan dengan semakin banyaknya anak-anak perempuan yang mengenyam pendidikan hingga ke tingkat perguruan tinggi.

Hasil olah data usia mahasiswa di UT Mataram menunjukkan terjadinya perubahan padadigma bahwa mahasiswa UT Mataram adalah orang-orang yang sudah tua, terutama guru-guru SD dan TK menjadi mahasiswa yang millenial. Hal ini ditunjukkan dengan dominasi usia mahasiswa UT Mataram yang menunjukkan sebagian besar pada umur dewasa (21 - 35 tahun)

\section{Pola penggunaan komunitas media sosial WhatsApp (X2)}

Pemanfaatan dan penggunaan komunitas media sosial WhatsApp setiap responden berbeda-beda. Hal ini sesuai denga motif dan kebutuhan informasi dari setiap responden. Berkaitan dengan pola penggunaan komunitas media sosial WhatsApp dalam mencari informasi dapat dilihat pada tabel 1 berikut ini.

Tabel 1

Pola penggunaan komunitas Media Sosial WhatsApp $\left(\mathrm{X}_{3}\right)$

\begin{tabular}{llcc}
\hline \multicolumn{2}{c}{$\begin{array}{c}\text { Pola penggunaan komunikas } \\
\text { media sosial WhatsApp }\end{array}$} & Jml & $\begin{array}{c}\text { Presentase } \\
(\%)\end{array}$ \\
\hline Jumlah & Sangat Rendah (1 & 1 & 0,3 \\
hari & hari) & 27 & 9,2 \\
& Rendah (2 - 3 hari) & 151 & 51,2 \\
& Tinggi (4 - 5 hari) & 116 & 39,3 \\
& Sangat Tinggi & & \\
& (>5hari) & & \\
\hline Jumlah & Sangat Rendah (1 & 4 & 1,4 \\
kunjung & kali) & 30 & 10,2 \\
an & Rendah (2 - 3 kali) & 157 & 53,2 \\
& Tinggi (4 - 5 kali) & 104 & 35,3 \\
& Sangat Tinggi & & \\
& (>5kali) & & \\
\hline Jumlah & Sangat Rendah (1- & 4 & 1,4 \\
waktu & 2 menit) & 30 & 10,2 \\
kunjung & Rendah (3 - 5 menit) & 157 & 53,2 \\
an & Tinggi (5 - 10 menit) & 104 & 35,3 \\
& Sangat Tinggi (>10 & & \\
& menit) & & \\
\hline
\end{tabular}

Pola penggunaan komunitas media sosial WhatsApp oleh responden sudah tergolong sedang dan tinggi. Hal ini sesuai dengan data yang disajikan pada tabel 1 dimana frekuensi kunjungan responden ke komunitas media sosialWhatsApp sebagian besar menjawab sedang dan tinggi. Kunjungan responden setiap minggu didominasi tinggi ( $4-5$ hari) sebanyak 151 orang $(51,2 \%)$ dan sangat tinggi (> hari) sebanyak 116 orang (39,3\%), jumlah kunjungan tinggi (4 - 5 kali) sebanyak 157 orang $(53,2 \%)$ dan sangat tinggi ( $>5$ kali) sebanyak 104 orang (35,3\%), serta jumlah waktu kunjungan tinggi (5 - 10 menit) sebanyak 157 orang $(53,2 \%)$ dan sangat tinggi (> 10 menit) sebanyak 104 orang (35,3\%). Hal ini menunjukkan bahwa tingkat kebutuhan informasi, kesadaran akan pentingnya komunitas selama menempuh pendidikan tinggi, dan interaksi responden sudah cukup tinggi.

\section{Tingkat pemenuhan kebutuhan informasi (Y)}

Tingkat pemenuhan kebutuhan informasi merupakan seberapa tinggi kebutuhan responden akan informasi terpenuhi selama bergabung dalam komunitas 
media sosial WhatsApp. Berkaitan dengan tingkat pemenuhan kebutuhan informasi responden dapat dilihat pada tabel 2 berikut ini.

Tabel 2

Tingkat Pemenuhan Kebutuhan Informasi (Y)

\begin{tabular}{llcc}
\hline \multicolumn{2}{c}{ Tingkat Pemenuhan } & Jml & $\begin{array}{c}\text { Presentase } \\
\text { Kebutuhan Informasi }\end{array}$ \\
\hline Tingkat & Sangat Rendah (1 & 2 & 0,7 \\
Pemenu & jenis) & 16 & 5,4 \\
han & Rendah $(2-3$ & 136 & 46,1 \\
& jenis $)$ & 141 & 47,8 \\
& Tinggi (4 - 5 jenis) & & \\
& Sangat Tinggi (>5 & & \\
& jenis) & & \\
\hline
\end{tabular}

Hasil penelitian pada tabel 2 di atas menunjukkan bahwa sebagian besar responden menjawab tingkat pemenuhan kebutuhan informasi sangat tinggi ( $>5$ jenis) sebanyak 141 orang $(47,8 \%)$ dan tinggi ( $4-5$ jenis) sebanyak 136 orang (46,1\%).Tingkat pemenuhan kebutuhan informasi responden di komunitas media sosial WhatsApp selama menempuh pendidikan tinggi di UT sudah terpenuhi. Responden merasa puas dan nyaman dengan keberadaan komunitas. Hal inilah yang menyebabkan responden dengan sukarela bergabung dan berbagi informasi dalam komunitas.

\section{Hubungan antara Karakteristik Mahasiswa dengan Pola Penggunaan Komunitas Media Sosial WhatsApp}

Faktor jenis kelamin, umur, pekerjaan dan informasi yang paling banyak dicari tidak memiliki hubungan yang nyata dengan pola penggunaan komunitas media sosial WhatsApp. Hal ini dapat dipahami karena anggota komunitas bersifat heterogen yang terdiri dari jenis kelamin, umur, latar belakang pekerjaan yang tidak sama. Faktor kepemilikan TIK memiliki hubungan yang sangat nyata dengan pola penggunaan komunitas media sosial WhatsApp. Hal ini dapat dipahami bahwa semakin tinggi kepemilikan media TIK, maka akan semakin sering berinteraksi dengan pihak lain dan mencari serta mendiseminasikan informasi dengan memanfaatkan berbagai media TIK yang dimilikinya.

\section{Tabel 3}

Nilai koefisien korelasi antara karakteristik responden dengan Pola Penggunaan Komunitas Media Sosial

WhatsApp

\begin{tabular}{lccc}
\hline \multirow{2}{*}{\begin{tabular}{c} 
Karaktersit $\begin{array}{c}\text { ik } \\
\text { Responden }\end{array}$ \\
\cline { 2 - 4 }
\end{tabular}} & $\begin{array}{c}\text { Jumlah } \\
\text { hari }\end{array}$ & $\begin{array}{c}\text { Jumlah } \\
\text { Kunjunga } \\
\mathrm{n}\end{array}$ & $\begin{array}{c}\text { Jumlah Waktu } \\
\text { Kunjungan }\end{array}$ \\
\hline $\begin{array}{l}\text { Jenis } \\
\text { kelamin }\end{array}$ & 0,033 & 0,048 & 0,068 \\
\hline Umur & 0,032 & 0,056 & 0,060 \\
\hline Pekerjaan & 0,012 & $-0,008$ & $-0,003$ \\
\hline
\end{tabular}

\begin{tabular}{|c|c|c|c|}
\hline $\begin{array}{l}\text { Kepemilika } \\
\text { n TIK }\end{array}$ & $0,153^{* *}$ & $0,153^{* *}$ & $0,168^{* *}$ \\
\hline $\begin{array}{l}\text { Informasi } \\
\text { yang paling } \\
\text { banyak } \\
\text { dicari }\end{array}$ & $-0,182^{* *}$ & $-0,118^{* *}$ & $-0,125^{* *}$ \\
\hline \multicolumn{4}{|c|}{$\begin{array}{l}\text { **nilai koefisien korelasi signifikan pada } \alpha=0.01 \\
\text { Berdasarkan hasil uji antara karakteristik responden } \\
\text { dengan pola Penggunaan komunitas WhatsApp pada } \\
\text { tabel } 3 \text { dapat dinyatakan bahwa hipotesispertama tidak } \\
\text { dapat diterima atau ditolak, yaitu tidak terdapat } \\
\text { hubungan nyata dan positif antara karakteristik } \\
\text { responden tidak memiliki hubungan nyata dan positif } \\
\text { dengan pola penggunaan komunitas WhatsApp. }\end{array}$} \\
\hline
\end{tabular}

\section{Hubungan antara Pola Penggunaan} Komunitas Media Sosial WhatsApp dengan Tingkat Pemenuhan Kebutuhan Informasi

Faktor motif mencari informasi memiliki hubungan yang sangat nyata dengan faktor jumlah hari, jumlah kunjungan, dan jumlah waktu kunjungan dalam pola penggunaan komunitas media sosial WhatsApp. Hal ini dapat dipahami bahwa semakin tinggi motif mencari informasi maka akan semakin tinggi jumlah kunjungan setiap hari, jumlah kunjungan, dan jumlah waktu yang dihabiskan untuk mencari dan mendiseminasikan informasi dalam komunitas media sosial WhatsApp.

\section{Tabel 4}

Nilai koefisien korelasi antara Motif Mencari dengan Pola Penggunaan Komunitas Media Sosial WhatsApp

\begin{tabular}{cccc}
\hline \multirow{2}{*}{$\begin{array}{c}\text { Motif mencari } \\
\text { informasi }\end{array}$} & \multicolumn{3}{c}{ Pola Penggunaan Komunitas } \\
\cline { 2 - 4 } & $\begin{array}{c}\text { Jumlah } \\
\text { hari }\end{array}$ & $\begin{array}{c}\text { Jumlah } \\
\text { Kunjungan }\end{array}$ & $\begin{array}{c}\text { Jumlah } \\
\text { Waktu } \\
\text { Kunjungan }\end{array}$ \\
\hline $\begin{array}{c}\text { Motif mencari } \\
\text { informasi }\end{array}$ & $0,484^{* *}$ & $0,473^{* *}$ & $0,506^{* *}$
\end{tabular}

*"nilai koefisien korelasi signifikan pada $\alpha=0.01$

Berdasarkan hasil uji yang disajikan pada tabel 4 menunjukkan bahwa terdapat hubungan yang nyata dan positif antara motif mencari informasi dengan pola penggunaan komunitas WhatsApp. Hal ini menunjukkan bahwa hipostesis kedua pada penelitian ini diterima, yaitu terdapat hubungan nyata dan positif antara motif mencari informasi memiliki hubungan nyata dengan pola penggunaan komunitas media sosial WhatsApp.

\section{Hubungan antara Pola Penggunaan Komunitas Media Sosial WhatsApp dengan Tingkat Pemenuhan Informasi}

Hasil uji pada tabel 5 menunjukkan terdapat hubungan yang nyata dan positif antara faktor jumlah hari, jumlah kunjungan, dan jumlah waktu kunjungan dalam pola penggunaan komunitas media sosial WhatsApp dengan tingkat pemenuhan informasi. Hal ini 
dapat dipahami karena semakin tinggi tingkat kunjungan pada komunitas media sosial WhatsApp, maka akan semakin tinggi pula tingkat pemenuhan kebutuhan informasi responden. Ini juga menunjukkan tingkat kepercayaan dan kepuasan yang tinggi responden terhadap komunitas. Semakin tinggi tingkat kepercayaan dan kepuasan, maka akan semakin tinggi pula tingkat kunjungan. Kepercayaan dan kepuasan ini menumbuhkan keinginan untuk selalu mengunjungi komunitas. Hal ini sesuai dengan pernyataan salah satu responden yang bernama Irwan Efendi berikut ini:

"saya bergabung dengan grup WA UPBJJ-UT Mataram karena banyak informasi yang dishare dalam grup berkaitan dengan kegiatan perkuliahan di Universitas Terbuka”.

\section{Tabel 5}

Nilai koefisien korelasi antara pola penggunaan media sosial WhatsApp dengan Tingkat Pemenuhan Informasi

\begin{tabular}{lc}
\hline $\begin{array}{c}\text { Pola Penggunaan } \\
\text { Komunitas Media Sosial } \\
\text { WhatsApp }\end{array}$ & $\begin{array}{c}\text { Tingkat Pemenuhan } \\
\text { Informasi }\end{array}$ \\
\hline Jumlah hari & $0,584^{* *}$ \\
\hline Jumlah kunjungan & $0,572^{* *}$ \\
\hline $\begin{array}{l}\text { Jumlah Waktu } \\
\text { Kunjungan }\end{array}$ & $0,582^{* *}$ \\
\hline **nilai koefisien korelasi signifikan pada $\alpha=0.01$
\end{tabular}

Hubungan nyata dan positif yang terjadi antara pola penggunaan media sosial WhatsApp dengan tingkat pemenuhan informasi menunjukkan bahwa hipotesis ketiga dalam penelitian ini diterima, yaituterdapat hubungan yang nyata dan positif antara pola Penggunaan komunitas WhatsApp memiliki hubungan nyata dengan tingkat pemenuhan informasi.

\section{SIMPULAN DAN SARAN}

Hasil penelitian ini menunjukkan bahwa Pertama, Frekuensi dan waktu yang digunakan oleh responden dalam mencari informasi di komunitas WhatsApp tergolong tinggi. Jenis informasi yang paling banyak dicari oleh responden adalah tutorial dan nilai. Faktor kepemilikan TIK dan motif mencari informasi memiliki hubungan yang sangat nyata dengan pola penggunaan komunitas WhatsApp, sedangkan faktor jenis kelamin, umur, pekerjaan dan informasi yang paling banyak dicari tidak memiliki hubungan yang nyata. Kedua, Tingkat pemenuhan kebutuhan informasi mahasiswa melalui komunitas WhatsApp tergolong tinggi. Faktor pola penggunaan komunitas WhatsApp seperti jumlah hari kunjungan, jumlah kunjungan, dan jumlah waktu kuncungan memiliki hubungan yang sangat nyata dengan tingkat pemenuhan informasi mahasiswa.

Saran yang dapat disampaikan berdasarkan hasil penelitian tentang pola penggunaan komunitas WhatsApp mahasiswa Universitas Terbuka Mataram adalah sebagai berikut: 1) Admin komunitas WhatsApp harus lebih up to date dalam menghimpun dan mendiseminasikan informasi serta segera memberikan umpan balik terhadap setiap pertanyaan dari anggota komunitas. 2) Bagi Universitas Terbuka Mataram perlu memberikan pembekalan kepada setiap staf yang bertugas sebagai admin komunitas WhatsApp sehingga informasi yang disampaikan kepada mahasiswa merupakan informasi yang valid dan uptodate. 3) Bagi pihak-pihak yang bergerak dibidang jasa pendidikan dapat memanfaatkan komunitas WhatsApp untuk mendiseminasikan informasi kepada peserta didiknya. Hal ini didasari atas tinggi penggunaan WhatsApp oleh masyarakat. Disamping itu aplikasi WhastApp mudah dalam penggunaan dan memiliki kelebihan dibandingkan aplikasi yang lain, yaitu lebih interaktif, efektif dan fleksibel.

\section{DAFTAR RUJUKAN}

(1) AR., M. Fikri. Konflik Agama dan Konstruksi New Media. Malang: UB Press. 2015. 221

(2) Nurhalimah, dkk. Media Sosial dan Masyarakat Pesisir: Refleksi Pemikiran Mahasiswa Bidikmisi. Deepublish Publisher, Yogyakarta.2019.(27)

(3) Hariwijaya, M. Metodologi dan Teknik Penulisan Skripsi, Tesis, Desertasi. Yogyakarta: Elmatera Publising, 2017.49.

(4) Lynch, J. D. Digital Public Library of America Service Hub Social Media Usage Analysis. 2019.

(5) Haryanto, Haryanto. Pemanfaatan Social Media Network Sebagai Media Komunikasi Komunitas Pustakawan Homogen Dalam Rangka Optimalisasi Resources Sharing Koleksi Antar Perguruan Tinggi. Pustakaloka. 2016. 8. 130. 10.21154/pustakaloka.v8i1.470.

(6) Setyani, N. I. Penggunaan media sosial sebagai sarana komunikasi bagi komunitas (Studi deskriptif kualitatif penggunaan media sosial Twitter, Facebook, dan Blog sebagai sarana komunikasi bagi komunitas akademi berbagi Surakarta). 2013.

(7) Angela, Natasha \& Yoedtadi, Moehammad. Pemanfaatan Media Sosial Oleh Komunitas Historia Indonesia. Prologia. 2019. 3. 393. 10.24912/pr.v3i2.6371.

(8) Lusiana, D., Widayatmoko, W., \& Pribadi, M. A. Pengaruh Penggunaan Media Sosial Instagram Terhadap Pemenuhan Kebutuhan Informasi Kuliner Para Followers Akun@ Jktfoodbang. Koneksi, 2018. 1(2), 315-322.

(9) Khotijah, I., \& Muhammad, F. Pengaruh Media Sosial Instagram@AgendaSolo dalam Pemenuhan Informasi bagi Pengguna Followers (Doctoral dissertation, IAIN Surakarta). 2020.

(10) Helen, H., \& Rusdi, F. Pengaruh Penggunaan Media Sosial Akun Instagram@ Jktinfo Terhadap Pemenuhan Kebutuhan Informasi Followers. Prologia, 2019. 2(2), 355362.

(11) Atika, A., Lubis, D. P., \& Rangkuti, P. A. Tingkat Pemenuhan Informasi Petani Melalui Radio Komunitas. Jurnal Aspikom, 2017. 3(3), 435-446.

(12) Joko, I. L. T. Pola Komunikasi Anak Melalui Media Sosial WhatsApp dengan Orang Tua di Perantauan (Studi di Desa Lailangga Kecamatan Wadaga Kabupaten Muna Barat). Jurnal Ilmu Komunikasi UHO: Jurnal Penelitian Kajian Ilmu Komunikasi dan Informasi, 2018. 3(2).

(13) Permatasari, E. M. A. Pola Komunikasi Jarak Jauh Antara Orang Tua Dan Anak Dalam Meningkatkan Tali 
74 CIVICUS : Pendidikan-Penelitian-Pengabdian Pendidikan Pancasila dan Kewarganegaraan | Vol. 8, No. 2, September 2020, hal 68-74

Silaturahmi Di Jurusan Komunikasi Dan Penyiaran Islam Angkatan 2013 (Doctoral dissertation, UIN Raden Intan Lampung). 2017.

(14) Nurjaman. Pola Komunikasi Kyai dalam Memelihara Solidaritas Jamaah. Academic Journal for Homiletic Studies, Vol 19 No 2, 2016. 305-330

(15) Sukrillah, A., Ratnamulyani, I. A., \& Kusumadinata, A. A. Pemanfaatan Media Sosial Melalui WhatsApp Group Fei Sebagai Sarana Komunikasi. Jurnal Komunikatio, 2018. 3 (2).

(16) Husna, N. Dampak Media Sosial terhadap Komunikasi Interpersonal Pustakawan di Perpustakaan UIN Sunan Kalijaga Yogyakarta. LIBRIA, 9(2), 2018. 183-196. 